\title{
Inhibition of Bcr - Abl kinase activity by PD180970 blocks constitutive activation of Stat5 and growth of CML cells
}

\author{
Mei Huang ${ }^{1,4}$, Jay F Dorsey ${ }^{1,4}$, PK Epling-Burnette ${ }^{2,4}$, Ramadevi Nimmanapalli2,4, \\ Terry H Landowski ${ }^{5}$, Linda B Mora ${ }^{1,4}$, Guilian Niu ${ }^{3,4}$, Dominic Sinibaldi ${ }^{1,4}$, Fanqi Bai ${ }^{2,4}$, \\ Alan Kraker ${ }^{6}$, Hua Yu ${ }^{3,4}$, Lynn Moscinski ${ }^{2,4}$, Sheng Wei ${ }^{3,4}$, Julie Djeu ${ }^{3,4}$, William S Dalton ${ }^{2,4}$, \\ Kapil Bhalla ${ }^{2,4}$, Thomas P Loughran ${ }^{2,4}$, Jie $\mathrm{Wu}^{1,4}$ and Richard Jove*,1,4 \\ ${ }^{1}$ Molecular Oncology, H Lee Moffitt Cancer Center, Research Institute, Tampa, Florida, FL 33612, USA; ${ }^{2}$ Experimental \\ Therapeutics, H Lee Moffitt Cancer Center, Research Institute, Tampa, Florida, FL 33612, USA; ${ }^{3}$ Immunology Programs, H Lee \\ Moffitt Cancer Center and Research Institute, Tampa, Florida, FL 33612, USA; ${ }^{4}$ Department of Oncology, University of South \\ Florida College of Medicine, Tampa, Florida, FL 33612, USA; ${ }^{5}$ Department of Medicine, University of Arizona Health Sciences \\ Center, Tucson, Arizona, AZ 85724, USA; ${ }^{6}$ Department of Cancer Research, Pfizer Global Research and Development, Ann Arbor, \\ Michigan, MI 48106, USA
}

Chronic myelogenous leukemia (CML) is a myeloproliferative disease characterized by the BCR - ABL genetic translocation and constitutive activation of the Abl tyrosine kinase. Among members of the Signal Transducers and Activators of Transcription (STAT) family of transcription factors, Stat5 is activated by the Bcr-Abl kinase and is implicated in the pathogenesis of CML. We recently identified PD180970 as a new and highly potent inhibitor of Bcr-Abl kinase. In this study, we show that blocking Bcr-Abl kinase activity using PD180970 in the human K562 CML cell line resulted in inhibition of Stat5 DNA-binding activity with an $\mathrm{IC}_{50}$ of $5 \mathrm{nM}$. Furthermore, abrogation of Abl kinase-mediated Stat5 activation suppressed cell proliferation and induced apoptosis in K562 cells, but not in the Bcr-Abl-negative myeloid cell lines, HEL 92.1.7 and HL-60. Dominant-negative Stat5 protein expressed from a vaccinia virus vector also induced apoptosis of $\mathrm{K562}$ cells, consistent with earlier studies that demonstrated an essential role of Stat5 signaling in growth and survival of CML cells. RNA and protein analyses revealed several candidate target genes of Stat5, including Bcl-x, Mcl-1, c-Myc and cyclin D2, which were down-regulated after treatment with PD180970. In addition, PD180970 inhibited Stat5 DNA-binding activity in cultured primary leukemic cells derived from CML patients. To detect activated Stat5 in CML patient specimens, we developed an immunocytochemical assay that can be used as a molecular end-point assay to monitor inhibition of Bcr-Abl signaling. Moreover, PD180970 blocked Stat5 signaling and induced apoptosis of STI-571 (Gleevec, Imatinib)-resistant BcrAbl-positive cells. Together, these results suggest that the mechanism of action of PD180970 involves inhibition of

\footnotetext{
*Correspondence: R Jove, Molecular Oncology Program, H. Lee Moffitt Cancer Center and Research Institute, 12902 Magnolia Drive, Tampa, Florida, FL 33612, USA; E-mail: richjove@moffitt.usf.edu Received 22 January 2002; revised 30 August 2002; accepted 4 September 2002
}

Bcr-Abl-mediated Stat5 signaling and provide further evidence that compounds in this structural class may represent potential therapeutic agents for CML.

Oncogene (2002) 21, 8804-8816. doi:10.1038/sj.onc. 1206028

Keywords: Stat5; Bcr-Abl; CML; PD180970; apoptosis; cell cycle

\section{Introduction}

CML is a myeloproliferative disease characterized by a well-defined genetic abnormality involving the BCR ABL translocation, which occurs in the Philadelphia $(\mathrm{Ph})$ chromosome (Rowley, 1973). This genetic alteration results from a chromosome 9:22 translocation that leads to expression of a chimeric fusion protein, BcrAbl, with deregulated tyrosine kinase activity (Lugo et al., 1990; Mes-Masson et al., 1986). The Bcr-Abl fusion protein and its constitutively-activated tyrosine kinase activity are essential for malignant progression in CML (Lugo et al., 1990; Pendergast et al., 1991). Because of this characteristic feature of CML, the $\mathrm{Bcr}-\mathrm{Abl}$ kinase is a good candidate for moleculartargeted chemotherapy. STI-571, originally known as CGP-57148B and now commercially available as Gleevec or Imatinib, is a selective $\mathrm{Bcr}-\mathrm{Abl}$ kinase inhibitor that has been shown to be highly efficacious for treatment of chronic phase CML in advanced clinical trials (Druker et al., 1996, 2001a,b). However, STI-571 is less effective during the blast crisis of CML and clinical resistance to STI-571 is already beginning to emerge (Druker et al., 2001a; Gorre et al., 2001). Therefore, it is important to continue developing additional new therapies for CML. We have previously shown that PD180970, which was originally selected as a Src kinase inhibitor, is a potent $\mathrm{Bcr}-\mathrm{Abl}$ kinase inhibitor and structurally similar compounds may thus 
represent potential novel therapeutic agents for CML (Dorsey et al., 2000; Kraker et al., 2000).

Earlier studies have demonstrated that multiple signal transduction pathways are involved in the abnormal growth signaling by $\mathrm{Bcr}-\mathrm{Abl}$, including Ras and phosphatidylinositol-3 kinase (Cortez et al., 1996; Jain et al., 1996; Puil et al., 1994). More recent studies have implicated one STAT family member, Stat5, as having an important role in $\mathrm{Bcr}-\mathrm{Abl}$ mediated transformation (Carlesso et al., 1996; Chai et al., 1997; de Groot et al., 1999; Frank and Varticovski, 1996; Ilaria and van Etten, 1996; Nieborowska-Skorska et al., 1999; Sillaber et al., 2000; Sonoyama et al., 2002). STATs comprise a family of transcription factors that were originally discovered as key effectors of normal cytokine signaling (Bromberg and Darnell, 2000). Numerous studies have subsequently shown that oncoproteins can activate STATs and that constitutively activated STAT signaling can directly contribute to oncogenic transformation (Besser et al., 1999; Bromberg et al., 1998; Catlett-Falcone et al., 1999; Chaturvedi et al., 1997; Danial et al., 1995; Nelson et al., 1998; Turkson et al., 1998; Yu et al., 1995; Zong et al., 1998). Constitutive activation of STATs has been observed in many malignant cell lines and tumor specimens, including multiple myeloma, lymphomas, leukemias, head and neck cancer, breast and prostate cancer (Bowman et al., 2000; Coffer et al., 2000; Danial and Rothman, 2000; Lin et al., 2000; Smithgall et al., 2000; Song and Grandis, 2000). Furthermore, mutationally activated forms of Stat3 and Stat5 have been shown to possess transforming properties, providing genetic evidence for the oncogenic potential of STATs (Bromberg et al., 1999; Onishi et al., 1998). In human K562 CML cells, disruption of constitutively-activated Stat5 signaling with dominant-negative Stat5 blocks colony formation in soft agar, suggesting that Stat5 has an essential role in Bcr-Abl-mediated transformation of these cells (de Groot et al., 1999).

In this study, we demonstrate that PD180970 can inhibit Stat5 DNA-binding activity in K562 CML cells with an $\mathrm{IC}_{50}$ of $5 \mathrm{nM}$, concomitant with a block in $\mathrm{Bcr}-\mathrm{Abl}$ autophosphorylation. Furthermore, inhibition of $\mathrm{Bcr}-\mathrm{Abl}$ is accompanied by induction of cell cycle arrest and apoptosis in $\mathrm{Ph}^{+}$K562 cells, but not in $\mathrm{Ph}^{-}$myeloid cell lines. Expression of dominantnegative Stat5 protein also induces apoptosis in K562 cells, consistent with a critical role of Stat5 signaling in growth and survival of CML cells. Growth inhibition by PD180970 correlates with down-regulation of the anti-apoptotic genes, Bcl- $\mathrm{x}_{\mathrm{L}}$ and $\mathrm{Mcl}-1$, and the cell cycle control genes, cyclin D2 and c-Myc, which are candidate Stat5-regulated genes. These findings suggest a molecular mechanism for the action of PD180970 involving inhibition of Stat5-mediated signal transduction and gene regulation downstream of $\mathrm{Bcr}-\mathrm{Abl}$. Inhibition of Stat5 signaling thus represents a potentially relevant molecular end-point for monitoring activity of $\mathrm{Bcr}-\mathrm{Abl}$ kinase inhibitors in vitro and in vivo. In addition, PD180970 inhibits Stat5 signaling and growth in CML patient specimens and STI-571resistant $\mathrm{Bcr}-\mathrm{Abl}$-positive cells, providing further evidence for the therapeutic potential of this class of compounds.

\section{Results}

PD180970 inhibits Abl tyrosine phosphorylation in human K562 CML cells

To confirm the effect of PD180970 on Bcr-Abl kinase activity, K562 cells were treated with increasing doses of PD180970 for $12 \mathrm{~h}$ before lysing the cells. Proteins were immunoprecipitated from cell lysates with antiAbl antibodies and Western blots were probed using
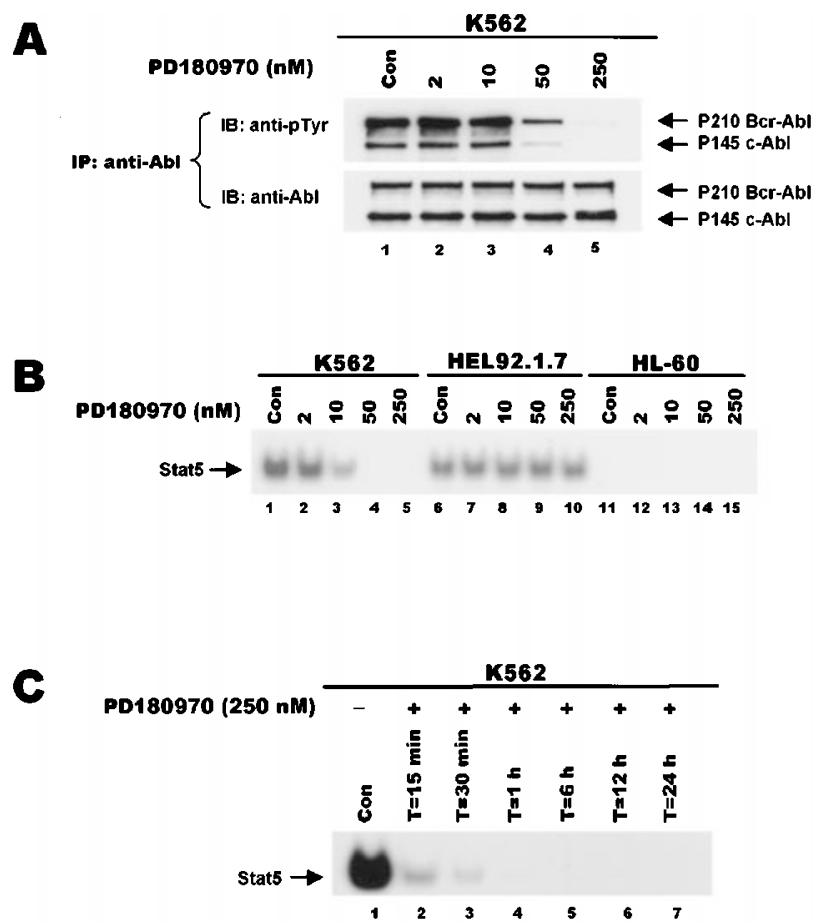

Figure 1 PD180970 inhibits $\mathrm{Bcr}-\mathrm{Abl}$ tyrosine phosphorylation and Stat5 activation in the $\mathrm{Ph}^{+} \mathrm{CML}$ cell line K562. (a) Immunoprecipitations were performed with anti-Abl antibody using lysates prepared from K562 cells treated for $12 \mathrm{~h}$ with DMSO vehicle (lane 1) or increasing concentrations of PD180970 (lanes $2-5$ ) and subjected to Western blot analyses. Upper panel shows the levels of Abl tyrosine phosphorylation as detected by antiphosphotyrosine (anti-pTyr) antibody. The lower panel was probed with anti-Abl antibody to confirm equal loading of proteins. Both $\mathrm{Bcr}-\mathrm{Abl}(210 \mathrm{kd})$ and $\mathrm{c}-\mathrm{Abl}(145 \mathrm{kd})$ proteins are detected by these antibodies. IP, immunoprecipitation; IB, immunoblot. (b) EMSA was performed to measure levels of Stat5 DNA-binding activity using nuclear extracts prepared from K562, HEL92.1.7 or HL-60 cells treated with the indicated doses of PD180970 for $24 \mathrm{~h}$. The ${ }^{32} \mathrm{P}$-labeled MGFe probe was used that specifically binds Stat5 in this assay. The position of activated Stat 5 bound to probe in the gel is indicated. (c) EMSA was performed to determine the kinetics of Stat5 inhibition following treatment with PD180970 in K562 cells for the indicated times, with redosing at $12 \mathrm{~h}$ for the $24 \mathrm{~h}$ time point. Experiments were repeated at least three times with similar results. Control (Con) lanes were treated with DMSO vehicle alone 
anti-phosphotyrosine antibodies to detect Abl phosphorylation or anti-Abl antibodies to detect total Abl proteins. Figure 1a shows that $\mathrm{Bcr}-\mathrm{Abl}$ tyrosine phosphorylation was blocked by PD180970 with an $\mathrm{IC}_{50}$ of $20 \mathrm{nM}$, indicating that PD180970 is a potent Abl kinase inhibitor, consistent with our earlier findings (Dorsey et al., 2000). Normal c-Abl phosphorylation was also inhibited with a similar $\mathrm{IC}_{50}$, while the total protein levels of both $\mathrm{Bcr}-\mathrm{Abl}$ and $\mathrm{c}-\mathrm{Abl}$ remained unchanged by treatment with PD180970.

\section{Stat5 DNA-binding activity is inhibited by PD180970 in K562 cells}

Because Stat5 has been shown to be a major signaling pathway downstream of Bcr-Abl (de Groot et al., 1999; Nieborowska-Skorska et al., 1999; Sillaber et al., 2000; Sonoyama et al., 2002), we investigated the effect of PD180970 on Stat5 DNA-binding activity. EMSA results shown in Figure $1 \mathrm{~b}$ demonstrate that treatment with PD180970 abolishes Stat5 DNA-binding activity in $\mathrm{K} 562$ cells with an $\mathrm{IC}_{50}$ of $5 \mathrm{nM}$. In contrast, Stat5 activity is not blocked in HEL92.1.7 cells, which do not possess the $\mathrm{Bcr}-\mathrm{Abl}$ translocation, indicating that Stat5 is activated through a Bcr-Abl-independent mechanism in the HEL cells. As another negative control for the studies described below, HL-60 cells were used that lack both the $\mathrm{Bcr}-\mathrm{Abl}$ protein and Stat5 activation. The kinetics of PD180970-mediated inhibition of Stat5 DNA-binding activity in K562 cells is shown in Figure 1c. Stat5 activation is inhibited by over $90 \%$ after 15 min of treatment with PD180970, and after $1 \mathrm{~h}$ of treatment there is no detectable Stat5 activity. Significantly, a single treatment with PD180970 inhibits Stat5 activation for at least $24 \mathrm{~h}$, suggesting that this compound is highly stable inside cells (data not shown). Thus, PD180970 induces rapid and prolonged inhibition of Bcr-Abl-mediated signaling through Stat5. Similar results (data not shown) were obtained using the structurally-related compounds, PD164199, PD173952 and PD173958 (Dorsey et al., 2002).

\section{PD180970 blocks proliferation of K562 cells}

To assess the effects of PD180970 on CML cell proliferation, $\left[{ }^{3} \mathrm{H}\right]$-thymidine incorporation assays were performed on K562 cells treated with PD180970. Figure 2a shows that proliferation of K562 cells was strongly inhibited by PD180970 with an $\mathrm{IC}_{50}$ of $20 \mathrm{nM}$. The levels of $\left[{ }^{3} \mathrm{H}\right]$-thymidine incorporation in K562 cells treated with $50 \mathrm{nM}$ of PD180970 were approximately $20 \%$ that of the control DMSO vehicle-treated cells. In addition, K562 cell number was decreased in a dose-dependent manner after treatment with PD180970 for 24 or $48 \mathrm{~h}$ (Figure 2b). In contrast, this compound had little effect on $\left[{ }^{3} \mathrm{H}\right]$-thymidine incorporation or proliferation in HEL and HL-60 cells that do not possess the $\mathrm{Bcr}-\mathrm{Abl}$ protein (Figure $2 \mathrm{a}$ and data not shown). Similar results were obtained with the related compounds, PD164199, PD173952 and PD173958
A

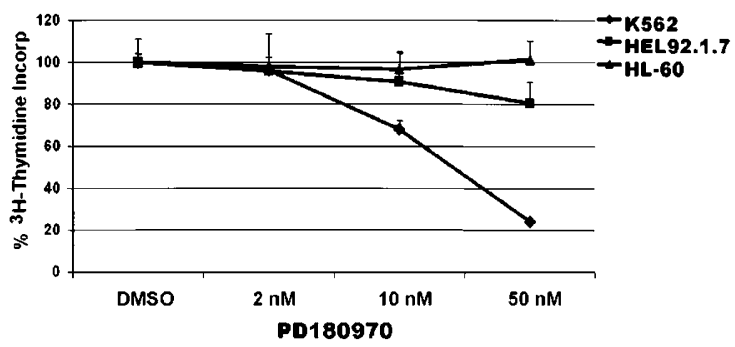

B

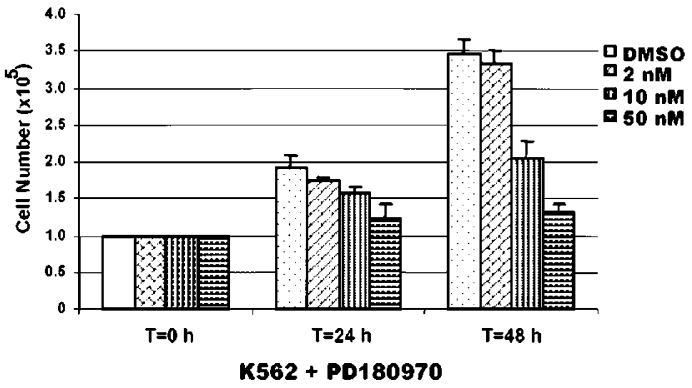

C

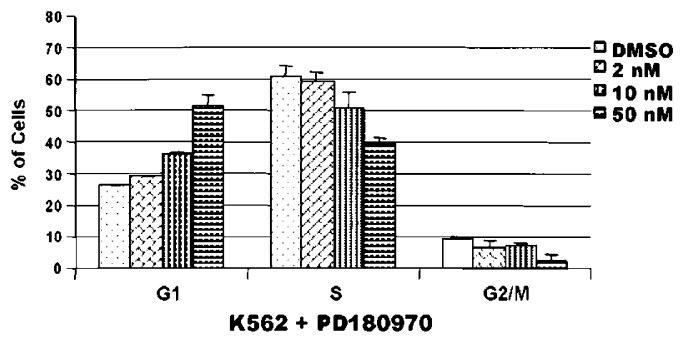

Figure 2 Treatment of K562 cells with PD180970 inhibits cell proliferation and induces cell cycle arrest. (a) Cell proliferation assays were performed using K562, HEL92.1.7 and HL-60 cells after $48 \mathrm{~h}$ treatment with increasing concentrations of PD180970 and addition of $\left[{ }^{3} \mathrm{H}\right]$-thymidine for the final $4 \mathrm{~h}$ of incubation. (b) Numbers of K562 cells were counted with a hemocytometer following treatment with PD180970 for 0, 24 or $48 \mathrm{~h}$. (c) Cell cycle analysis was performed by flow cytometry using PI staining combined with BrdU incorporation following $24 \mathrm{~h}$ treatment with PD180970. The percentage of cells in G1 and G2/M were determined by PI staining, while the percentage in S phase was determined by BrdU incorporation. Graphical data shown are the means plus standard deviations of one representative experiment out of three independent experiments, each performed in triplicate

(data not shown), consistent with earlier studies (Dorsey et al., 2002). Inhibition of cell proliferation by PD180970 and related compounds correlated well with inhibition of Stat5 DNA-binding activity in K562 cells as described above.

\section{Treatment with PD180970 induces G1 cell cycle arrest in} K562 cells

To determine if there are cell cycle changes associated with the inhibition of K562 cell proliferation, cell cycle profiles were examined using combined PI staining and BrdU incorporation followed by flow cytometry. Figure 2c shows that K562 cells were arrested in G1 phase in a dose-dependent manner after $24 \mathrm{~h}$ treatment 
with PD180970. The percentage of cells in G1 after treatment with $50 \mathrm{nM}$ of PD180970 was nearly double that of control cells. The $\mathrm{S}$ phase distribution was substantially decreased with $50 \mathrm{nM}$ of PD180970, showing that DNA synthesis was also diminished, probably as a result of the G1 arrest. These results demonstrate that inhibition of $\mathrm{Bcr}-\mathrm{Abl}$ and Stat5 signaling is associated with cell cycle arrest in the $\mathrm{Ph}^{+}$ K562 cell line. In contrast, there were no changes in cell cycle distribution in the $\mathrm{Ph}^{-}$cell lines, HEL92.1.7 and HL-60 (data not shown).

\section{K562 cells undergo apoptosis in response to PD180970 treatment}

To further characterize the role of $\mathrm{Bcr}-\mathrm{Abl}$ and activated Stat 5 in growth control of K562 cells, the effect of PD180970 on apoptosis was examined by flow

A

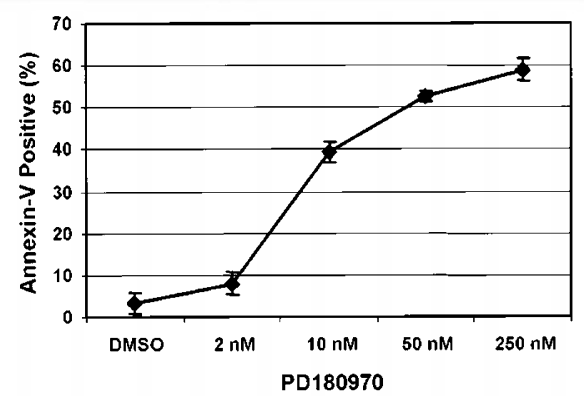

B

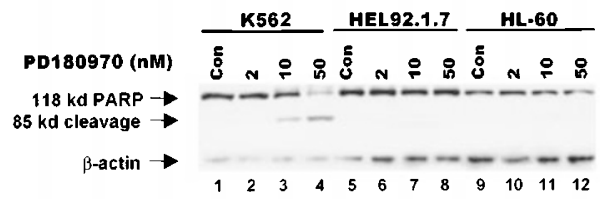

C

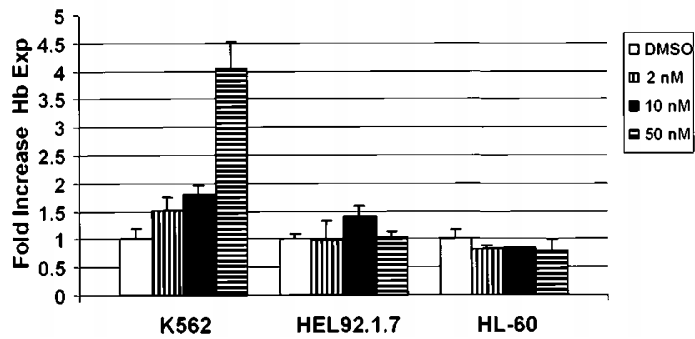

Figure 3 Treatment of K562 cells with PD180970 induces apoptosis and hemoglobin expression. K562, HEL92.1.7 and HL-60 cells were treated with the indicated doses of PD180960 for $48 \mathrm{~h}$. (a) Apoptosis assays were performed by flow cytometry using combined Annexin-V and 7-AAD staining in K562 cells. (b) Effects of PD180970 on PARP cleavage were determined by Western blot analysis with anti-PARP antibody. Cleavage of p118 PARP yields an $85 \mathrm{kd}$ proteolytic product indicative of apoptosis. Normalization of total protein loading was verified by probing with antibodies to $\beta$-actin. (c) Effects of PD180970 on hemoglobin protein expression were determined by colorimetric assay. Graphical data shown are the means plus standard deviations of one representative experiment out of three independent experiments, each performed in triplicate cytometry. Figure $3 \mathrm{a}$ shows that after $48 \mathrm{~h}$ of exposure to PD180970, Annexin V-positive staining was increased dramatically in $\mathrm{K} 562$ cells with an $\mathrm{IC}_{50}$ of approximately $20 \mathrm{nM}$. By contrast, in the $\mathrm{Ph}^{-}$cell lines, HEL92.7.1 and HL-60, treatment with PD180970 had no effect on Annexin-V staining (data not shown). Induction of apoptosis was confirmed by cleavage of PARP, as shown in Figure 3b. Again, these changes were not observed in the $\mathrm{Ph}^{-}$cell lines following treatment with PD180970. These results indicate that PD180970 induces apoptosis in $\mathrm{Ph}^{+}$cells that is associated with inhibition of $\mathrm{Bcr}-\mathrm{Abl}$ and Stat5 activation.

Because previous studies showed that STI-571 induces differentiation of $\mathrm{Bcr}-\mathrm{Abl}$-positive leukemic cells (Fang et al., 2000), we examined the effect of PD180970 on differentiation of K562 cells. After 48 h treatment with PD180970, hemoglobin expression was measured as an indicator of differentiation in leukemic cells. As shown in Figure 3c, hemoglobin protein expression was induced in K562 cells by PD180970 in a dose-dependent manner, and at $50 \mathrm{nM}$ PD180970 the expression of hemoglobin was fourfold higher than the DMSO control. By contrast, this induction of hemoglobin was not seen in the Bcr-Abl-negative cell lines.
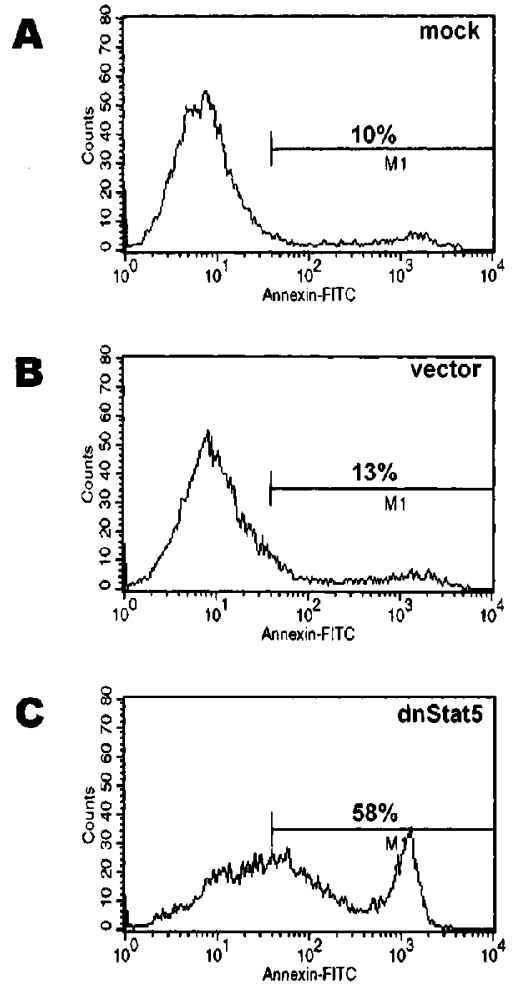

Figure 4 Expression of dominant-negative Stat 5 protein induces apoptosis of K562 cells. Cells were either mock infected (a) or infected with control vaccinia virus (b) or vaccinia virus encoding dominant-negative Stat5 protein (c). Viral infections of K562 cells were carried out as described in Materials and methods. After $24 \mathrm{~h}$ of infection, apoptosis was measured by Annexin V-FITC staining followed by flow cytometry 
Dominant-negative Stat5 induces apoptosis of K562 cells

Because PD180970 is expected to inhibit other signaling pathways in addition to Stat5 that lie downstream of $\mathrm{Bcr}-\mathrm{Abl}$, the effects of dominantnegative Stat5 protein on the growth and survival of K562 cells were evaluated. As shown in Figure 4, dominant-negative Stat5 protein expressed from a vaccinia virus vector induced a dramatic increase in Annexin V-positive staining of infected K562 cells compared to mock-infected or control vector-infected cells. These findings indicate a critical role for Stat5 signaling in preventing apoptosis of K562 cells, consistent with earlier studies that demonstrated a requirement for Stat5 in growth and survival of $\mathrm{Bcr}-$ Abl-positive cells (de Groot et al., 1999; NieborowskaSkorska et al., 1999; Sillaber et al., 2000; Sonoyama et al., 2002).

PD180970 inhibits expression of cell cycle and apoptosis control genes

Potential downstream target genes of Stat5 that could be responsible for the growth inhibition and apoptosis induced by PD180970 in K562 cells were analysed by RNase protection assays using probes for multiple genes, including Bcl-2 family members and cell cycle control genes. Figure $5 \mathrm{a}$ shows that $\mathrm{Bcl}-\mathrm{x}_{\mathrm{L}}$ and $\mathrm{Mcl}-1$ mRNA levels were down-regulated at least twofold after treatment for $36 \mathrm{~h}$ with PD180970. In addition, we observed that expression of the cyclin D2 gene was down-regulated by treatment with PD180970 in a dosedependent manner (Figure 5a). Western blot analyses confirmed that expression levels of $\mathrm{Bcl}-\mathrm{x}_{\mathrm{L}}, \mathrm{Mcl}-1$ and cyclin D2 proteins were also reduced following downregulation of their mRNA expression (Figure 5c).

The effect of PD180970 on c-Myc RNA expression was assessed by Northern blot analysis. Figure $5 \mathrm{~b}$ demonstrates that c-Myc mRNA levels in K562 cells were dramatically decreased after treatment with PD180970, whereas treatment of the HEL91.1.7 and HL-60 cells had no effect on c-Myc expression (data not shown). Taken together, our data show that PD180970 can inhibit cell cycle progression and survival in K562 cells, accompanied by down-regulation of $\mathrm{Bcl}-\mathrm{x}_{\mathrm{L}}, \mathrm{Mcl}-1$, cyclin D2 and c-Myc gene expression. In all cases, the $\mathrm{IC}_{50}$ of this downregulation of gene expression is approximately 5$20 \mathrm{nM}$, similar to the $\mathrm{IC}_{50}$ for inhibition of $\mathrm{Bcr}-\mathrm{Abl}$ tyrosine phosphorylation and Stat5 DNA-binding activity (Figure 1a,b).

\section{PD180970 inhibits Stat5 signaling and induces apoptosis in CML patient specimens}

To determine whether PD180970 could inhibit Stat5 DNA-binding activity in $\mathrm{Bcr}-\mathrm{Abl}$ positive blasts, fresh peripheral blood $\mathrm{CD}^{+} 4^{+}$mononuclear cells from patients with CML were purified and incubated $e x$ vivo with PD180970. EMSA results shown in Figure $6 \mathrm{a}$ demonstrate that in four out of five patient specimens
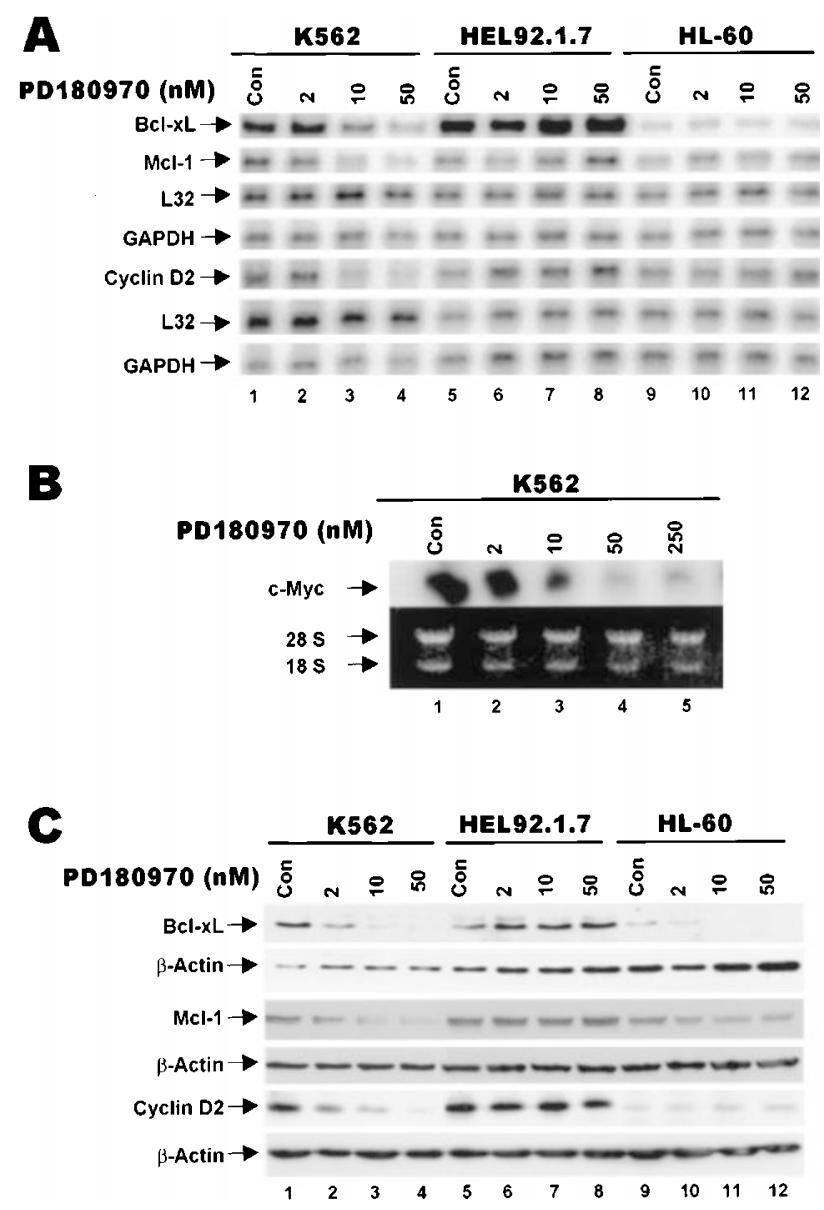

Figure 5 PD180970 inhibits expression of anti-apoptosis genes and cell cycle control genes in K562 cells. (a) RNase protection assays were performed to measure levels of mRNA expression of the indicated genes in K562, HEL92.1.7 and HL-60 cells treated with increasing concentrations of PD180970 for $36 \mathrm{~h}$. Normalization of total RNA was achieved using the L32 and GAPDH genes as internal controls for each set of template probes. (b) Northern blot analysis was performed to detect cMyc mRNA expression levels in K562 cells after exposure to the indicated doses of PD180970 for $36 \mathrm{~h}$. Normalization of total RNA was verified by ethidium bromide staining of $28 \mathrm{~S}$ and $18 \mathrm{~S}$ ribosomal RNAs. (c) The protein expression levels for selected genes was confirmed by Western blot analyses following treatment of cells with increasing doses of PD180970. Normalization of total protein was confirmed by re-probing each Western blot with antibodies to $\beta$-actin. Experiments were repeated at least three times with similar results

examined, treatment with PD180970 for $24 \mathrm{~h}$ effectively blocked Stat5 DNA-binding activity. Availability of limited amounts of patient material restricted the number of experiments that could be performed. In the single specimen tested for supershift analysis with antibodies to Stat5, the DNA-binding activity was positively identified as corresponding to Stat5 (lane 10). In two patient specimens for which there was adequate material to perform a dose-response experiment, $10 \mathrm{nM}$ was sufficient to completely block Stat5 DNA-binding activity (lanes 3 and 14). By contrast, in another patient specimen, the DNA-binding activity was completely resistant to $250 \mathrm{nM}$ PD180970 (lanes 11 


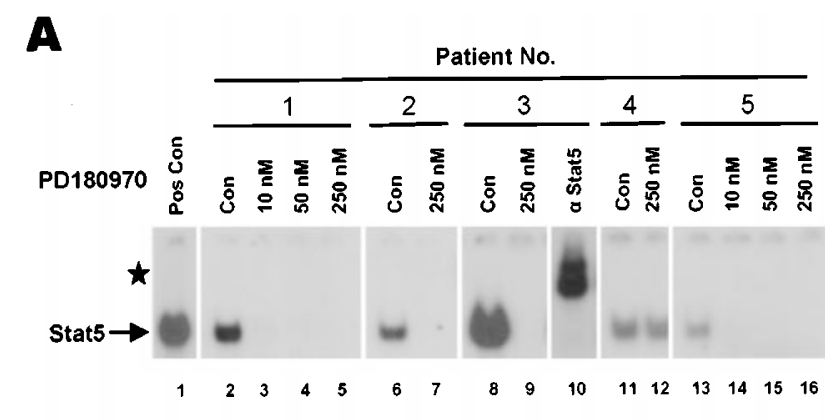

B

$\mathrm{T}=48 \mathrm{~h}$ Treatment with PD180970 (No. 3 Patient)
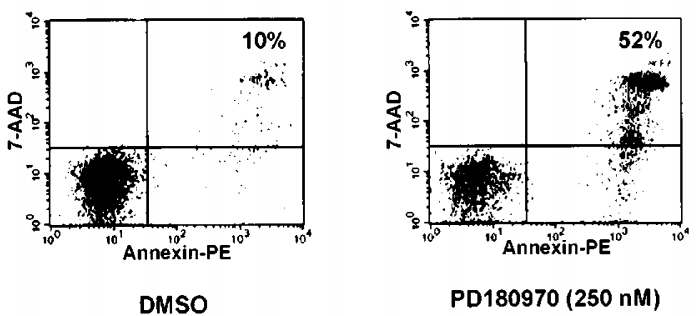

Figure 6 Inhibition of Stat5 DNA-binding activity in primary CML patient specimens treated ex vivo with PD180970. Fresh peripheral blood CD34 ${ }^{+}$mononuclear cells purified as described in Materials and methods were incubated ex vivo with PD180970 and then assayed for levels of Stat5 DNA-binding activity and apoptosis. (a) EMSA of Stat5 DNA binding to radiolabeled MGFe probe after $24 \mathrm{~h}$ treatment with PD180970 at the indicated concentrations or DMSO (Con) vehicle alone. The positive control (Pos Con) was K562 cells, and the star indicates the position of band that was supershifted by anti-Stat5 (lane 10) antibodies. (b) Apoptosis was determined after $48 \mathrm{~h}$ treatment with DMSO or $250 \mathrm{~nm}$ PD180970 for one patient specimen. Staining with 7-AAD (vertical axis) is indicative of total dead cells, while Annexin-V staining (horizontal axis) is specific for apoptotic cells. Percentages indicate the apoptosis-specific cell death. Similar results were obtained with a second CML patient specimen (patient no. 5, data not shown)

and 12). Apoptosis was assayed by Annexin-V staining and flow cytometry of one specimen (patient no. 3) treated ex vivo with either DMSO vehicle alone or 250 nM PD180970. Figure 6b shows that this treatment with PD180970 induced a fivefold increase in apoptosis (up to $52 \%$ ) of CML tumor cells. Similar results were obtained with the tumor cells from a second patient (data not shown). These findings indicate that PD180970 can block Stat5 signaling and induce apoptosis of primary $\mathrm{Bcr}-\mathrm{Abl}$ positive leukemic cells from CML patients.

\section{Immunocytochemical assay for detection of activated Stat5 in CML cells}

We developed an immunocytochemical assay for direct detection of activated phospho-Stat5 in CML tumor cells. Figure 7 (panels A1-C1) shows staining of K562 cells with antibodies to phospho-Stat5 after treatment with DMSO vehicle alone or increasing concentrations of PD180970. Results demonstrate that levels of phospho-Stat5 were greatly diminished at $10 \mathrm{nM}$ and completely abolished at $50 \mathrm{nM}$ PD180970. Figure 7,
Panels A2-C2 show phospho-Stat5 staining in fresh peripheral blood progenitor cells from a CML patient (patient no. 5). Purified CD34 ${ }^{+}$mononuclear cells were incubated ex vivo with the indicated concentrations of PD180970 prior to staining. Results demonstrate that levels of phospho-Stat5 were abrogated at $10 \mathrm{nM}$ PD180970, and at $50 \mathrm{nM}$ compound the morphological features of apoptosis are clearly evident in the patient specimen. These results are consistent with the EMSA analyses (compare with Figure 6, lanes 13-15) and indicate that this immunohistochemical assay for phospho-Stat5 can be applied when limited amounts of sample are available or to identify specific cell types harboring activated Stat5.

\section{STI-571-resistant Bcr-Abl-positive cells are inhibited by PD180970}

Because of the emerging clinical resistance to STI-571 treatment among CML patients (Druker et al., 2001a; Gorre et al., 2001), it was of interest to determine the sensitivity of STI-571 resistant cells to PD180970. As models of resistant leukemic cells, we used K562 cells and HL-60 cells stably expressing ectopic p185 BcrAbl (HL-60BA cells) that were isolated under continuous selection for growth in the presence of STI-571 (Nimmanapalli et al., 2002). The STI-571-resistant K562 cell line, Re-K562, has lost Bcr-Abl expression, while the resistant HL-60BA cell line, Re-HL-60BA, expresses elevated levels of $\mathrm{Bcr}-\mathrm{Abl}$ protein (Nimmanapalli et al., 2002). As shown in Figure 8, Re-K562 cells lack Stat5 DNA-binding activity (panel a, lane 5) and have lost sensitivity to PD180970-induced apoptosis as measured by Annexin V staining (panel b), consistent with the loss of $\mathrm{Bcr}-\mathrm{Abl}$ expression. In contrast, the HL-60BA cells expressing Bcr-Abl have acquired Stat5 DNA-binding activity that is inhibited by PD180970 (Figure 8a, lanes 3 and 4) and have also acquired sensitivity to PD180970-induced apoptosis (Figure 8b). By comparison, the parental HL-60 cells lacking $\mathrm{Bcr}-\mathrm{Abl}$ expression do not exhibit Stat5 DNA-binding activity (Figure 1b) or PD180970induced apoptosis (Figure 3b). Significantly, the STI571-resistant Re-HL-60BA cells have retained sensitivity to PD180970 in terms of both Stat5 DNA-binding activity (Figure 8a, lanes 7 and 8) and apoptosis (Figure 8b). Thus, sensitivity to PD180970 in these cell lines is associated with $\mathrm{Bcr}-\mathrm{Abl}$-mediated Stat5 signaling, and is retained in STI-571 resistant cells expressing $\mathrm{Bcr}-\mathrm{Abl}$.

\section{Discussion}

We investigated the effects of the $\mathrm{Bcr}-\mathrm{Abl}$ kinase inhibitor, PD180970, on constitutively active Stat5 signaling in human K562 CML cells harboring activated $\mathrm{Bcr}-\mathrm{Abl}$. While previous studies have demonstrated that $\mathrm{Bcr}-\mathrm{Abl}$ is required for growth and survival of CML cells (Druker et al., 1996; Lugo et al., 1990), the signaling pathways involved have not 


\section{K562 cell line}

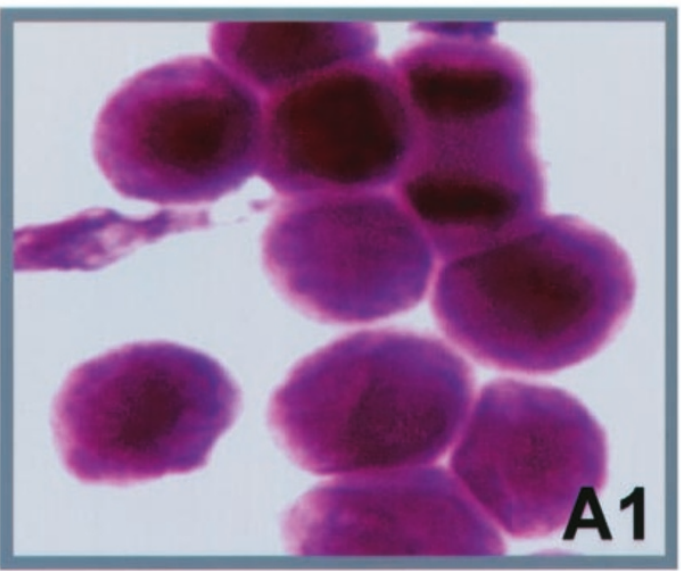

CML patient

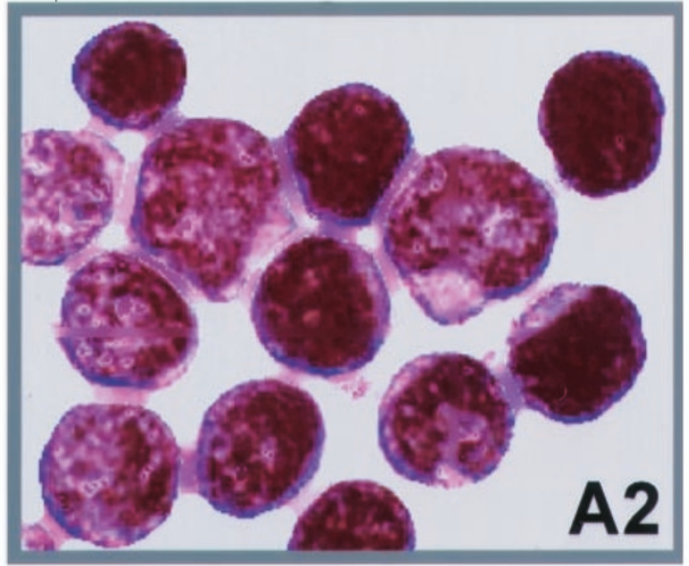

\section{DMSO Control}
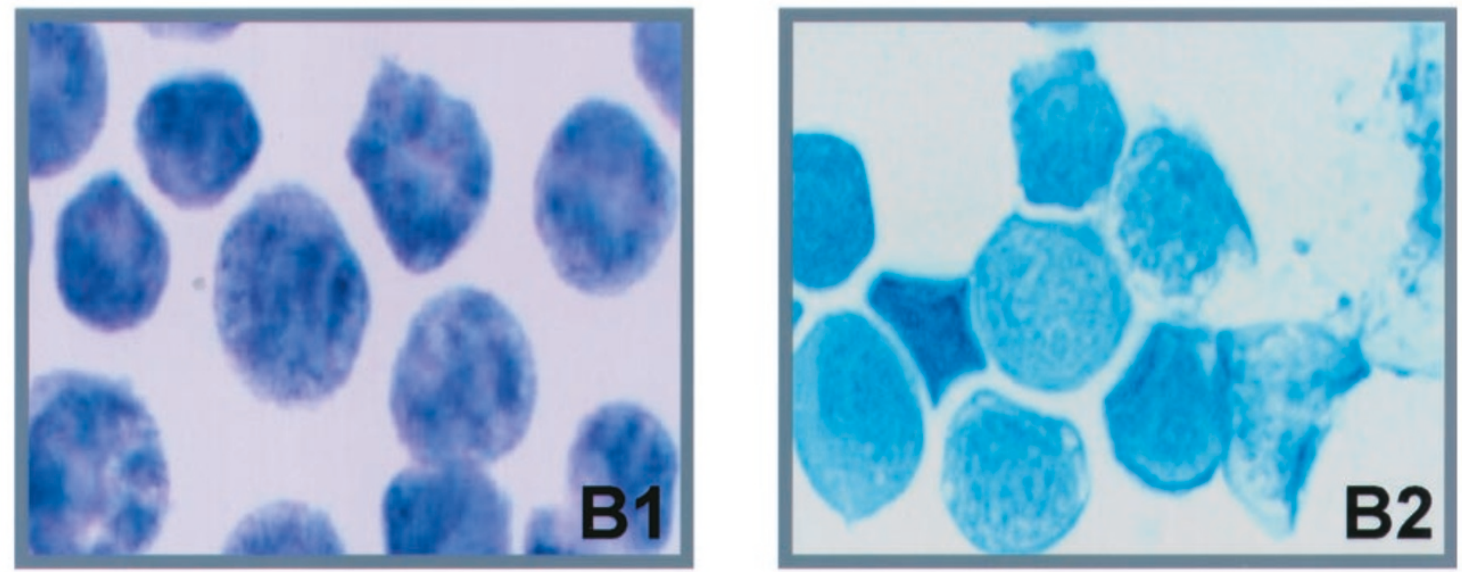

\section{0 nM PD180970}
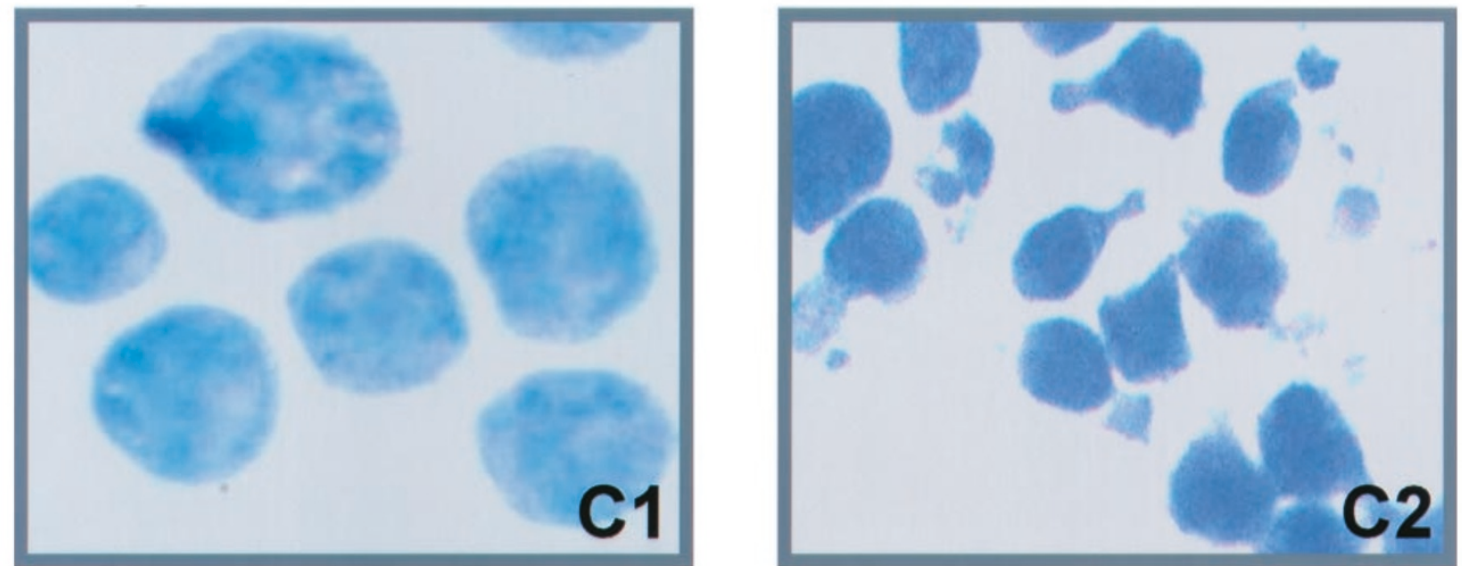

\section{0 nM PD180970}

Figure 7 Immunocytochemical detection of activated phospho-Stat5 in K562 cells and primary leukemic blasts after treatment $e x$ vivo with PD180970. Cytospins of K562 cells or purified CML patient CD34 ${ }^{+}$mononuclear cells were immunostained with antibodies to phosphotyrosine-Stat5 as described in Materials and methods. Cells were incubated ex vivo for 24 h with PD180970 prior to immunostaining. (A1 - C1) K562 cells were treated with DMSO vehicle alone or the indicated concentrations of PD180970. (A2C2) $\mathrm{CD} 34^{+}$mononuclear cells were purified from the peripheral blood of a CML patient (patient no. 5) and treated with DMSO or the indicated concentrations of PD180970 ex vivo 


\section{A}

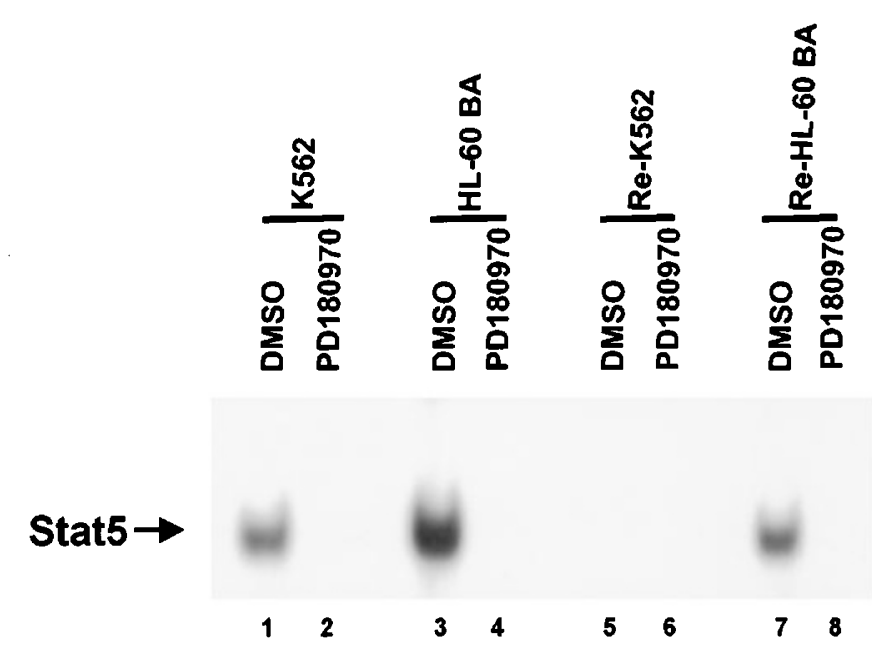

\section{B}

K562

HL-60BA
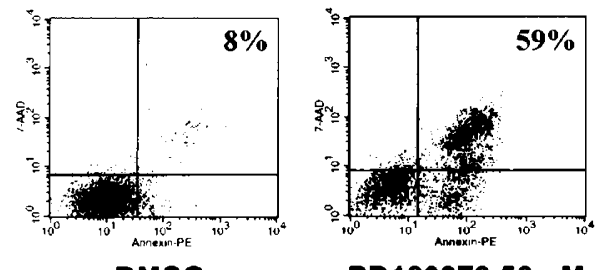

DMSO

PD180970 50 nM
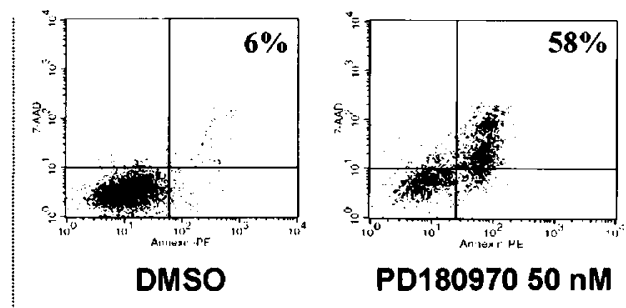

PD180970 50 nM
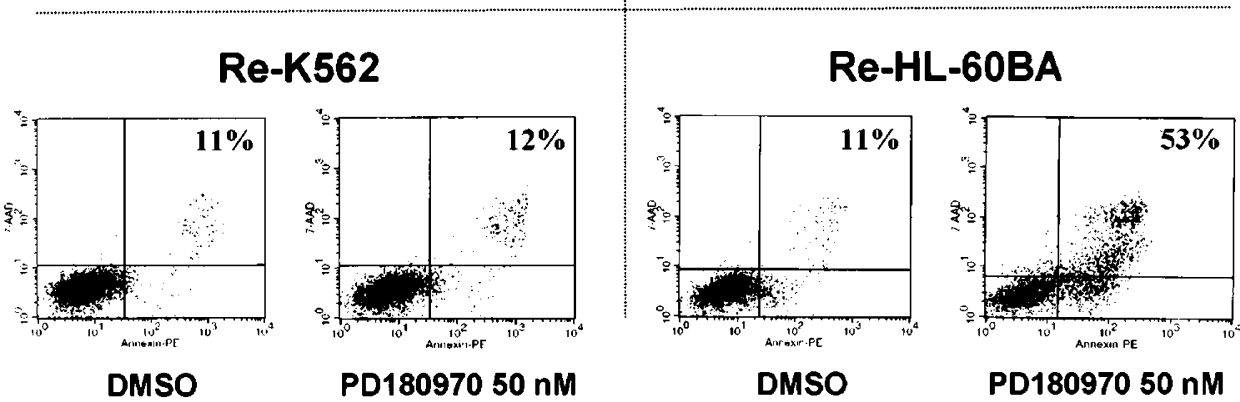

Figure 8 PD180970 inhibits Stat5 signaling and induces apoptosis in Bcl-Abl-positive leukemic cells resistant to STI-571. (a) EMSA was performed to measure levels of Stat5 DNA-binding activities in nuclear extracts prepared from K562 cells and HL60BA cells expressing ectopic Bcl-Abl protein, as well as their STI-571 resistant counterparts, Re-K562 and Re-HL-60BA. The Re-K562 cells have lost Bcl-Abl expression, whereas Re-HL-60BA cells have retained Bcl-Abl expression. Cells were treated with DMSO vehicle or $50 \mathrm{~nm}$ PD180970 as indicated for $24 \mathrm{~h}$. (b) Cell lines in a were treated with DMSO or $50 \mathrm{~nm}$ PD180970 for $48 \mathrm{~h}$ and then assayed for apoptosis by flow cytometry using combined Annexin-V and 7-AAD staining

been fully delineated. We show here that blocking Bcr-Abl kinase activity repressed Stat5 DNA-binding activity at low nanomolar concentrations of PD180970, accompanied by growth inhibition and induction of apoptosis. Furthermore, this block in growth and survival was associated with inhibition of candidate Stat5-regulated genes involved in controlling cell cycle progression and apoptosis. By contrast, the compound did not induce these responses in HEL92.1.7 and HL60 human myeloid leukemia cells that lack Bcr-Abl expression, indicating that the inhibitory effects of PD180970 depend on the presence of activated BcrAbl kinase. Moreover, our findings are consistent with earlier studies that demonstrated a requirement for Stat5 signaling in Bcr-Abl-mediated transformation of myeloid cell lines (de Groot et al., 1999; NieborowskaSkorska et al., 1999; Sillaber et al., 2000; Sonoyama et al., 2002).

Bcl- $\mathrm{x}_{\mathrm{L}}$, one of the anti-apoptotic genes of the Bcl-2 family, has been shown to suppress apoptosis of hematopoietic cells (Benito et al., 1996; Ibrado et al., 1996). In the human multiple myeloma cell line, U266, blocking Stat 3 reduced Bcl- $\mathrm{x}_{\mathrm{L}}$ expression and induced apoptosis (Catlett-Falcone et al., 1999). It has also been reported that $\mathrm{Bcl}-\mathrm{x}_{\mathrm{L}}$ expression is dependent on Stat5 signaling in cells transfected with $\mathrm{Bcr}-\mathrm{Abl}$ or 
with dominant-negative Stat5 protein expression vectors (Gesbert and Griffin, 2000). Furthermore, other studies have shown that the $\mathrm{Bcl}-\mathrm{x}_{\mathrm{L}}$ promoter contains a Stat5-binding site, which regulates $\mathrm{Bcl}-\mathrm{x}_{\mathrm{L}}$ transcriptional activity downstream of $\mathrm{Bcr}-\mathrm{Abl}$ kinase (Horita et al., 2000). Our results show that blocking Bcr-Abl kinase decreases Stat5 DNA-binding activity, reduces Bcl- $\mathrm{x}_{\mathrm{L}}$ expression and induces apoptosis of K562 cells after treatment with PD180970. In addition, we report that $\mathrm{Mcl}-1$ is another candidate downstream target gene of Stat5 in K562 cells. Mcl-1 is a survival factor in hematopoietic cells (Reynolds et al., 1994; Zhou et al., 1997) and previously has been shown to be regulated by Stat3 in neutrophils and LGL leukemia cells (Epling-Burnette et al., 2001a,b). We show here that Mcl-1 expression was decreased in K562 cells after treatment with PD180970, in parallel with inhibition of Stat5 signaling. Thus, Stat5-mediated $\mathrm{Bcl}-\mathrm{x}_{\mathrm{L}}$ and $\mathrm{Mcl}-1$ expression may contribute to survival of CML cells induced by $\mathrm{Bcr}-\mathrm{Abl}$.

PD180970 induces G1 cell cycle arrest in the $\mathrm{Ph}^{+}$ K562 cells as demonstrated by cell cycle analysis. A decreased number of G1-arrested cells at $48 \mathrm{~h}$ compared to $24 \mathrm{~h}$ correlates with an increase in Annexin V-positive apoptotic cells present at $48 \mathrm{~h}$ (our unpublished results), suggesting that G1 arrest precedes apoptosis in response to PD180970. Cell cycle control genes have been implicated in signaling downstream of $\mathrm{Bcr}-\mathrm{Abl}$ and expression of $\mathrm{Bcr}-\mathrm{Abl}$ can induce cells to progress from G1 to $\mathrm{S}$ phase (Jonuleit et al., 1998). Our studies show that cyclin D2 is downregulated by PD180970, suggesting that it may be a Stat5 target gene downstream of $\mathrm{Bcr}-\mathrm{Abl}$. Consistent with our findings, cyclin D2 also has been shown to be down-regulated in Stat5a/b knockout mice (Socolovsky et al., 1999). In addition, the c-Myc oncogene is found over-expressed and amplified in many diverse human tumors and regulates cell proliferation (Dang et al., 1999; Obaya et al., 1999). Furthermore, earlier studies have established that c-Myc is involved in Bcr-Ablmediated oncogenesis (Afar et al., 1994; Sawyers et al., 1992), although the pathways leading to c-Myc induction by $\mathrm{Bcr}-\mathrm{Abl}$ have not been fully defined. Recently, Stat3-mediated c-Myc expression has been shown to be required for Src oncogenesis and PDGFinduced mitogenesis (Bowman et al., 2001). Our present study demonstrates that after treatment of K562 cells with PD180970, the c-Myc RNA expression levels are dramatically inhibited. These findings are consistent with earlier studies showing that IL-2 induces c-Myc expression in a Stat5-dependent manner (Lord et al., 2000). Thus, Bcr-Abl may induce c-Myc expression by activation of Stat5 signaling, although it remains to be determined whether Stat5 regulates the cMyc promoter directly or indirectly in this context.

In striking contrast to numerous studies that demonstrated a requirement for Stat5 signaling in Bcr-Abl-mediated transformation of myeloid cell lines (de Groot et al., 1999; Nieborowska-Skorska et al., 1999; Sillaber et al., 2000; Sonoyama et al., 2002), one isolated study with $\mathrm{Stat} 5 \mathrm{a} / \mathrm{b}$ null mice suggests that
Stat5 signaling is not required for transformation by Bcr-Abl (Sexl et al., 2000). It is possible that these discrepancies reflect differences in the model systems used for $\mathrm{Bcr}-\mathrm{Abl}$ transformation in these studies. For example, significant differences have been noted in signaling pathways required for induction of CML-like myeloproliferative disease compared to B-lymphoid leukemias (Roumiantsev et al., 2001). In these latter studies, the Src homology 2 (SH2) domain of $\mathrm{Bcr}-\mathrm{Abl}$ was found to be required for efficient induction of myeloid leukemia-like disease in mice but not for lymphoid leukemogenesis (Roumiantsev et al., 2001). The $\mathrm{Bcr}-\mathrm{Abl} \mathrm{SH} 2$ domain is also required for Stat5 activation associated with leukemogenesis in myeloid lineage cells (Nieborowska-Skorska et al., 1999). Other studies showed that apoptosis is induced in myeloid cells by inhibiting $\mathrm{NF}-\kappa \mathrm{B}$ signaling in cells that lack activated Stat5 signaling, but not in myeloid cells that contain activated Stat5 signaling (Gelfanov et al., 2001). These findings suggest that Stat5 signaling is important for survival pathways in myeloid cells, and thus may underlie differences in requirements for Stat5 signaling in myeloproliferative compared to lymphoproliferative disease. Significantly, $\mathrm{Bcr}-\mathrm{Abl}^{\mathrm{P} 210}$ transformation of bone marrow cells in wild-type Stat5 mice induced eight cases of myeloid leukemia out of nine total leukemias; however, there were only two cases of myeloid leukemia out of 11 total leukemias in Stat $5 \mathrm{a} / \mathrm{b}$ null mice, indicating that Stat5 has an important role in myeloid leukemia (Sexl et al., 2000). In contrast, recent studies with $\mathrm{Stat} 5 \mathrm{a} / \mathrm{b}$ null mice demonstrated that Stat5 is essential for both myeloproliferative and lymphoproliferative disease induced by the Tel-Jak2 oncoprotein (Schwaller et al., 2000). Furthermore, expression of a constitutivelyactivated mutant form of Stat5a was sufficient by itself to induce myeloproliferative but not lymphoproliferative disease (Schwaller et al., 2000). Here we show that dominant-negative Stat5 expressed from a vaccinia virus vector induces apoptosis of K562 cells, providing further evidence that Stat5 signaling is essential for growth and survival of CML cells. Thus, the requirements for Stat5 signaling in transformation are highly dependent on both the cell type as well as the oncogenic stimulus, probably reflecting differences in the dependence on various signaling pathways for growth and survival.

STI-571 is the first $\mathrm{Bcr}-\mathrm{Abl}$ selective inhibitor that has been demonstrated to possess potent anti-tumor activity in CML patients (Druker et al., 2001a,b). Importantly, STI-571 is a prototype tyrosine kinase inhibitor that validates the concept of molecular targeted-therapy (Druker et al., 1996, 2001b). However, clinical resistance to STI-571 has already been reported in $\mathrm{CML}$ patients and additional therapies will be required for more effective treatment during blast phase (Druker et al., 2001a, Gorre et al., 2001; Porosnicu et al., 2001; Thiesing et al., 2000). Our results demonstrate that $\mathrm{PD} 180970$ is another potent $\mathrm{Bcr}-\mathrm{Abl}$ kinase inhibitor and thus this class of compounds represents a starting point for the devel- 
opment of new therapeutics. The potential advantages of PD180970 are the low nanomolar $\mathrm{IC}_{50}$ as well as the finding that STI-571-resistant cells retain sensitivity to PD180970 in a Bcr-Abl-dependent manner. These observations are consistent with the finding that PD180970 induced apoptosis of CD34 ${ }^{+}$leukemic cells isolated from three patients who had progressive leukemia while receiving STI-571 (Nimmanapalli et al., 2002). Because PD180970 is also a potent inhibitor of Src family kinases, we cannot exclude the possibility that the potency of this compound derives from its ability to inhibit both $\mathrm{Bcr}-\mathrm{Abl}$ and $\mathrm{Src}$ kinase activities (Dorsey et al., 2000; Kraker et al., 2000). In this regard, it is likely to be relevant that Src family kinases cooperate with $\mathrm{Bcr}-\mathrm{Abl}$ in cell transformation (Lionberger et al., 2000). Other Src kinase inhibitors structurally related to PD180970, including PD164199, PD173952 and PD173958, are also effective inhibitors of Bcr-Abl-dependent cell growth (Dorsey et al., 2002), in good agreement with their abilities to inhibit Stat5 signaling (our unpublished data). Recent studies by another group have independently confirmed the potent inhibitory activity of PD180970 and related compounds, including PD166326 and PD173955, on Bcr-Abl-dependent cell growth (Wisniewski et al., 2002). Furthermore, resolution of the crystal structure of the $\mathrm{Bcr}-\mathrm{Abl}$ kinase domain complexed with PD173955 revealed that this compound may achieve its high potency by binding to both the active and inactive conformations of Abl, while STI-571 binds exclusively to the inactive conformation of Abl (Nagar et al., 2002). The preferential binding of these two compounds to different conformations of $\mathrm{Bcr}-\mathrm{Abl}$ may also explain the ability of PD180970 to inhibit the growth of STI-571-resistant leukemic cells.

Our findings reported here suggest that inhibition of Stat5 signaling downstream of Bcr-Abl may be an important mechanism of action of PD180970 as well as of other $\mathrm{Bcr}-\mathrm{Abl}$ inhibitors, including STI-571. The involvement of Stat5 signaling does not preclude a critical role for additional signaling pathways downstream of $\mathrm{Bcr}-\mathrm{Abl}$, such as CrkL (Kolibaba et al., 1999; Rhodes et al., 2000). Based on our findings, Stat5 signaling is another potentially relevant molecular endpoint that could be used for monitoring the efficacy of $\mathrm{Bcr}-\mathrm{Abl}$ inhibitors in patients. For this purpose, the immunocytochemical assay for phospho-Stat5 described here can be readily adapted to detect levels of activated Stat5 in CML cells of patients following drug treatment. Analysis of a limited number of CML patient specimens demonstrated that PD180970 inhibits Bcr-Abl-mediated Stat5 signaling ex vivo and induced apoptosis in two specimens for which there was sufficient material to perform this assay.

In summary, compounds in the structural class of PD180970 represent potential candidates for treatment of $\mathrm{Bcr}-\mathrm{Abl}$ positive leukemias. Furthermore, Stat5 signaling may contribute to the molecular mechanism of action of $\mathrm{Bcr}-\mathrm{Abl}$ inhibitors as well as serve as a molecular end-point for assaying their activities in vitro and in vivo.

\section{Materials and methods}

Cell lines and Bcr-Abl kinase inhibitors

K562, HEL92.1.7 and HL-60 cells were obtained from the American Type Culture Collection. The STI-571 resistant cell lines, Re-K562 and Re-HL-60BA, have been previously described (Nimmanapalli et al., 2002). Cells were grown in RPMI 1640 containing $10 \%$ heat-inactivated FBS and 100 units/ml penicillin-streptomycin. The pyrido[2,3- $d]$ pyrimidine derivative PD180970 and related compounds, PD164199, PD173952 and PD173958, were synthesized by Pfizer Global Research and Development (Ann Arbor, MI, USA) and have been previously described (Kraker et al., 2000; Dorsey et al., 2000, 2002). Compounds were added to cultured cells at the indicated concentrations dissolved in dimethyl sulphoxide (DMSO).

\section{Leukemic blasts from CML patients}

All patients met the clinical criteria of $\mathrm{Ph}$ chromosomepositive CML in either chronic phase $(<10 \%$ blasts in the bone marrow, patient no. 4), accelerated phase (11-29\% blasts in the bone marrow, patient no. 2), or blast crisis ( $>30 \%$ blasts in the bone marrow, patient nos. 1, 3, 5). Informed consents were signed by all patients to allow use of their cells for these experiments as part of a clinical protocol approved by the local Institutional Review Board. Peripheral blood $(50 \mathrm{ml})$ was obtained in heparinized tubes and peripheral blood mononuclear cells (PBMCs) were isolated by centrifugation through Ficoll-Hypaque (Amersham Pharmacia Biotech). To isolate $\mathrm{CD}_{4} 4^{+}$leukemic blasts from PBMCs, the cells were coated with anti-CD34-phycoerythrin (PE) conjugated antibody (Pharmingen) and anti-PEmicrobeads (Miltenyi Biotech). The $\mathrm{CD}^{+}{ }^{+}$cells were then isolated using magnetic cell sorting (MACS) with LS + columns and Variomax magnets (Miltenyi Biotech). The MACS-selected cells were analysed by flow cytometry prior to and after sorting to determine the percentage of CD $34^{+}$ cells and extent of purification. In all cases, CD $34^{+}$cells were enriched to greater than $90 \%$ purity using this technique.

\section{Nuclear extracts and electrophoretic mobility shift assay}

Nuclear extract preparation and electrophoretic mobility shift assay (EMSA) analysis of STAT DNA-binding activity were performed as previously described (Catlett-Falcone et al., 1999; Turkson et al., 1998; Yu et al., 1995). Briefly, cells were treated with PD180970 or DMSO vehicle alone for $24 \mathrm{~h}$ prior to preparation of nuclear extracts. Nuclei were isolated and extracted in hypertonic buffer (20 mM HEPES, pH 7.9, $420 \mathrm{mM} \mathrm{NaCl}, 1 \mathrm{~mm}$ EDTA, $1 \mathrm{mM}$ EGTA, 20\% glycerol, $20 \mathrm{~mm} \mathrm{NaF}, 1 \mathrm{~mm} \mathrm{Na} \mathrm{VO}_{4}, 1 \mathrm{~mm} \mathrm{Na} \mathrm{P}_{4} \mathrm{O}_{7}, 1 \mathrm{~mm}$ DTT, $0.5 \mathrm{mM}$ PMSF, $0.1 \mu \mathrm{M}$ aprotinin, $1 \mu \mathrm{M}$ leupeptin and $1 \mu \mathrm{M}$ antipain). Extracts were normalized for total protein, and $4-$ $8 \mu \mathrm{g}$ of nuclear protein were incubated with ${ }^{32} \mathrm{P}$-labeled MGFe (mammary gland factor element) probe (de Groot et al., 1999) derived from the bovine $\beta$-casein gene promoter $\left(5^{\prime}\right.$ AGATTTCTAGGAATTCAA-3'). Protein-DNA complexes were resolved on $5 \%$ nondenaturing polyacrylamide gels and detected by autoradiography.

\section{Flow cytometry for cell cycle and apoptosis assays}

For cell cycle analysis following treatment of cells with different concentrations of PD180970 for 24 or $48 \mathrm{~h}$, BrdU incorporation assays in combination with propidium iodide 
(PI) staining were performed essentially as described previously (Hazlehurst et al., 2000). Approximately $1 \times 10^{6}$ cells per sample were used for processing and analysis of fluorescence on a Becton-Dickinson FACScan using Cell Quest software. For apoptosis analysis, $1 \times 10^{6}$ cells were treated with different doses of PD180970 for 24 or $48 \mathrm{~h}$ before harvesting. Annexin V-binding assays were used to evaluate the extent of apoptosis by flow cytometry following staining with Annexin V-PE or Annexin V-FITC combined with 7-AAD (PharMingen) as previously described (EplingBurnette et al., 2001a).

\section{Cell proliferation assays}

Thymidine incorporation assays were performed in triplicate with $1 \times 10^{4}$ cells/well exposed to the indicated doses of PD180790 for $48 \mathrm{~h}$. Cells were pulsed with $\left[{ }^{3} \mathrm{H}\right]$-thymidine $(0.25 \mu \mathrm{Ci}$ /well $)$ during the last $4 \mathrm{~h}$ of culture. Cells were then transferred from the plates onto glass fiber filters and $\left[{ }^{3} \mathrm{H}\right]$ thymidine incorporation was determined using a liquid scintillation counter.

\section{Hemoglobin assays}

After treatment with different doses of PD180970, cells were harvested and lysed by four cycles of freezing and thawing at $-80^{\circ} \mathrm{C}$ for differentiation assays as measured by hemoglobin protein levels (Fang et al., 2000). Lysates were centrifuged to remove cellular debris, the protein concentration in the supernatant was determined, and $25 \mu \mathrm{g}$ of total protein was diluted in $100 \mu \mathrm{l} \mathrm{H} \mathrm{H}_{2} \mathrm{O}$. Ten $\mu \mathrm{l}$ of benzidine- $\mathrm{HCl} \quad(10 \mathrm{mg}$ benzidine into $1 \mathrm{ml} 0.5 \%$ acetic acid), $45 \mu \mathrm{l}$ of supernatant protein, $55 \mu \mathrm{l}$ of $\mathrm{H}_{2} \mathrm{O}$ and $5 \mu \mathrm{l} \mathrm{H}_{2} \mathrm{O}_{2}$ were added to 96 well plates. The plates were analysed by a spectrophotometer with $90 \mathrm{~s}$ at $\lambda=620$.

\section{Western blot analyses}

Whole-cell lysates were prepared in boiling SDS sampleloading buffer to extract total proteins from cells treated with PD180970 for $48 \mathrm{~h}$. Western blot analyses were performed as previously described (Catlett-Falcone et al., 1999; EplingBurnette et al., 2001a). The primary antibodies used were monoclonal anti-Bcl- $\mathrm{x}_{\mathrm{L}}$ (SC-634; $1: 500$ dilution), monoclonal anti-Mcl-1 (SC-958; 1:1000), and monoclonal anti-cyclin D2 (SC-181; $1:$ 1000) from Santa Cruz Biotechnology. Polyclonal antibodies to poly(ADP-ribose) polymerase (PARP; 1:3000) were from Roche. Proteins were detected by enhanced chemiluminescence (ECL) using rabbit anti-mouse secondary antibodies as previously described (Epling-Burnette et al., 2001a).

\section{Bcr-Abl immunoprecipitation}

Whole-cell lysates were prepared in IP buffer $(25 \mathrm{mM}$ Tris$\mathrm{HCl}, \mathrm{pH} 7.2,150 \mathrm{~mm} \mathrm{NaCl}, 25 \mathrm{~mm} \mathrm{NaF}, 0.5 \mathrm{~mm} \mathrm{Na}$ orthovanadate, $20 \mathrm{mM}$ PNPP, $1 \mathrm{~mm}$ benzamidine, $1 \mathrm{~mm}$ DTT, $1 \%$ Triton X-100, $2 \mu \mathrm{g} / \mathrm{ml}$ aprotinin, $2 \mu \mathrm{g} / \mathrm{ml}$ leupeptin, $1 \mu \mathrm{g} / \mathrm{ml}$ pepstatin, $100 \mu \mathrm{g} / \mathrm{ml}$ PMSF). Bcr-Abl was immunoprecipitated by addition of mouse monoclonal antic-Abl (SC-23; Santa Cruz Biotechnology) for $30 \mathrm{~min}$ at $4{ }^{\circ} \mathrm{C}$ and incubation with protein $\mathrm{G}$-agarose for $3 \mathrm{~h}$ at $4^{\circ} \mathrm{C}$. Beads were washed in IP buffer and $1 \times$ SDS loading buffer was added. Samples were boiled, resolved by SDS-PAGE, transferred and blotted with monoclonal PY20 anti-phosphotyrosine (BD Transduction Labs) or c-Abl antibodies (Santa Cruz Biotechnology).

\section{$R N A$ isolation and RNase protection assays}

Total RNA was isolated from $5 \times 10^{6}$ cells using TRIzol reagent (Gibco-BRL). RNase protection assays (RPA) were carried out with the Riboquant hAPO-2 (Bcl-2 family members), hCYC1 (cyclin family) and hCC1 (cell cycle control family) multi-probe templates (PharMingen) as previously described (Landowski et al., 1999). Briefly, the multi-probe templates were synthesized by in vitro transcription with incorporation of $\left[{ }^{32} \mathrm{P}\right]$-dUTP and purified on Quick Spin RNA columns (Roche). Specific activity was quantified in a scintillation counter and probe $\left(0.5-1 \times 10^{6}\right.$ c.p.m. $\left./ \mu \mathrm{l}\right)$ was hybridized with $10 \mu \mathrm{g}$ of total RNA through a temperature range of $90^{\circ} \mathrm{C}$ to $56^{\circ} \mathrm{C}$ over $16-18 \mathrm{~h}$, followed by RNase digestion at $37^{\circ} \mathrm{C}$ for $1 \mathrm{~h}$. Protected RNA fragments were separated on a $5 \%$ polyacrylamide denaturing gel and quantified with ImageQuant software (Molecular Dynamics, Sunnyvale, CA, USA).

\section{Northern blot analyses}

Total RNA preparation and Northern blot analysis were performed as previously described (Sinibaldi et al., 2000). A total of $10 \mu \mathrm{g}$ of RNA was resolved on a $1 \%$ agaroseformaldehyde gel, transferred to a nylon membrane and probed with a ${ }^{32} \mathrm{P}$-labeled probe corresponding to the $1.4 \mathrm{~kb}$ XhoI fragment of murine c-myc cDNA. Detection of $28 \mathrm{~S}$ and $18 \mathrm{~S}$ ribosomal RNA by ethidium bromide staining confirmed equalization and integrity of samples.

\section{Vaccinia virus delivery of dominant-negative Stat5 protein}

Recombinant vaccinia virus encoding dominant-negative Stat5 was constructed using the pSP11 vector in recombination with the WR strain of vaccinia. Vaccinia virus containing kinase-deficient (KD) PAK1 was kindly provided by $\mathrm{Dr}$ Elizabeth Hong-Geller (Los Alamos National Laboratory, Los Alamos, NM, USA). As a control for viral infection, vaccinia virus expressing CD56, a large granular lymphocyte-specific surface marker, was used. The procedure of vaccinia viral generation and infection have been previously described (Wei et al., 2000; Jiang et al., 2000). Briefly, K562 cells $\left(5 \times 10^{6}\right)$ per treatment group were incubated with the vaccinia virus constructs for $2 \mathrm{~h}$ at $37^{\circ} \mathrm{C}$ in serum-free medium at a multiplicity of infection (MOI) of six. The cells were washed and then further incubated in serum-containing medium for $24 \mathrm{~h}$ at $37^{\circ} \mathrm{C}$ prior to the flow cytometric analysis.

\section{Immunocytochemistry to detect activated phospho-Stat5 protein}

Immunostaining for phospho-Stat5 was performed using a rabbit anti-human polyclonal antibody against tyrosine phosphorylated Stat5 (Phospho-Stat5 Tyr694; Cell Signaling, Beverly, MA, USA). As negative controls, rabbit immunoglobulins (Vector, Burlingame, CA, USA) were used to replace the primary antibodies. The immunohistochemical staining was performed manually at room temperature, using the avidin-biotin - peroxidase complex methods (Vectastatin Elite ABC kit; Vector Lab). Briefly, pretreatment for antigen retrieval with a pressure cooker involved heating cytospins in a microwave oven in $250 \mathrm{ml}$ of unmasking solution (Vector Lab) for $20 \mathrm{~min}$ at high power level, followed by $20 \mathrm{~min}$ of cooling time. Slides were then treated with $0.025 \%$ trypsin in $50 \mathrm{~mm}$ Tris- $\mathrm{HCl}, \mathrm{pH} 7.6$, for $5 \mathrm{~min}$ at $37^{\circ} \mathrm{C}$ without prewarming. Endogenous peroxidase and nonspecific background staining were blocked by incubating slides with $3 \%$ 
hydrogen peroxide for $10 \mathrm{~min}$. After rinsing with PBS for 5 min, slides were blocked with normal serum and 3\% BSA for $10 \mathrm{~min}$, followed by incubation with the phospho-Stat5 primary antibodies, at a dilution of $1: 400$, overnight at $4{ }^{\circ} \mathrm{C}$. After rinsing with PBS for $5 \mathrm{~min}$, slides were incubated with biotinylated secondary antibody for $60 \mathrm{~min}$ at room temperature and washed again with PBS. Slides were then incubated with avidin-biotin complex for $1 \mathrm{~h}$ and rinsed with PBS. The chromogen was developed with Nova-red (Nova-red Substrate kit for peroxidase, Vector Lab). All

\section{References}

Afar D, Goga A, McLaughlin J, Witte O and Sawyers C. (1994). Science, 264, 424-426.

Benito A, Silva M, Grillot D, Nunez G and Fernandez-Luna J. (1996). Blood, 87, 3837-3843.

Besser D, Bromberg JF, Darnell JE and Hanafusa H. (1999). Mol. Cell. Biol., 19, $1401-1409$.

Bowman T, Broome M, Sinibaldi D, Wharton W, Pledger W, Sedivy J, Irby R, Yeatman T, Courtneidge $\mathrm{S}$ and Jove R. (2001). Proc. Natl. Acad. Sci. USA, 98, 7319-7324.

Bowman T, Garcia R, Turkson J and Jove R. (2000). Oncogene, 19, 2474-2488.

Bromberg J and Darnell JE. (2000). Oncogene, 19, 2468 2473.

Bromberg J, Horvath CM, Besser D, Lathem WW and Darnell JE. (1998). Mol. Cell. Biol., 18, $2553-2558$.

Bromberg J, Wrzeszczynska M, Devgan G, Zhao Y, Pestell R, Albanese C and Darnell JE. (1999). Cell, 98, 295-303.

Carlesso N, Frank DA and Griffin JD. (1996). J. Exp. Med., 183, $811-820$.

Catlett-Falcone R, Landowski T, Oshiro M, Turkson J, Levitzki A, Savino R, Ciliberto G, Moscinski L, Fernandez-Luna J, Nunez G, Dalton W and Jove R. (1999). Immunity, 10, 105-115.

Chai SK, Nichols GL and Rothman P. (1997). J. Immunol., 159, $4720-4728$.

Chaturvedi P, Sharma S and Reddy EP. (1997). Mol. Cell. Biol., 17, $3295-3304$.

Coffer P, Koenderman L and de Groot R. (2000). Oncogene, 19, $2511-2522$.

Cortez D, Stoica G, Pierce J and Pendergast A. (1996). Oncogene, 13, 2589-2594.

Danial NN, Pernis A and Rothman P. (1995). Science, 269, $1875-1877$.

Danial NN and Rothman P. (2000). Oncogene, 19, $2523-$ 2531.

Dang C, Resar L, Emison E, Kim S, Li Q, Prescott J, Wonsey D and Zeller KL. (1999). Exp. Cell Res., 253, 63-77.

de Groot R, Raaijmakers J, Lammers J, Jove R and Koenderman L. (1999). Blood, 94, 1108-1112.

Dorsey J, Cunnick J, Lanehart R, Huang M, Kraker A, Bhalla K, Jove R and Wu J. (2002). Leukemia, 16, $1589-$ 1595.

Dorsey J, Jove R, Kraker A and Wu J. (2000). Cancer Res., 60, 3127-3131.

Druker B, Sawyers C, Kantarjian H, Resta D, Reese S, Ford J, Capdeville R and Talpaz M. (2001a). N. Engl. J. Med., 344, $1038-1042$.

Druker B, Talpaz M, Resta D, Peng B, Buchdunger E, Ford J, Lydon N, Kantarjian H, Capdeville R, Ohno-Jones S and Sawyers C. (2001b). N. Engl. J. Med., 344, 1031-1037.

Druker B, Tamura S, Buchdunger E, Ohno S, Segal G, Fanning S, Zimmermann J and Lydon N. (1996). Nat. Med., 2, $561-566$.
PD180970 inhibits Stat5 and CML growth

M Huang et al

slides were counter-stained with hematoxylin for $30 \mathrm{~s}$ before dehydration and mounting.

\section{Acknowledgements}

This work was supported by NCI grants CA55652 and CA82533 (to R Jove). We thank members of the laboratory for valuable discussions and the Moffitt Cancer Center Tumor Bank, Flow Cytometry and Molecular Imaging Core Facilities.

Epling-Burnette $\mathrm{P}$, Liu J, Catlett-Falcone R, Turkson J, Oshiro M, Kothapalli R, Li Y, Wang J, Yang-Yen H, Karras J, Jove R and Loughran TJ. (2001a). J. Clin. Invest., 107, $351-362$.

Epling-Burnette $\mathrm{P}$, Zhong B, Bai F, Jiang K, Bailey R, Garcia R, Jove R, Djeu J, Loughran TJ and Wei S. (2001b). J. Immunol., 166, 7486-7495.

Fang G, Kim C, Perkins C, Ramadevi N, Winton E, Wittmann S and Bhalla K. (2000). Blood, 96, 2246-2253.

Frank DA and Varticovski L. (1996). Leukemia, 10, 1724 1730.

Gelfanov V, Burgess GS, Litz-Jackson S, King AJ, Marshall MS, Nakshatri H and Boswell HS. (2001). Blood, 98, $2508-2517$.

Gesbert F and Griffin J. (2000). Blood, 96, 2269-2276.

Gorre M, Mohammed M, Ellwood K, Hsu N, Paquette R, Rao P and Sawyer SC. (2001). Science, 293, 876-880.

Hazlehurst L, Damiano J, Buyuksal I, Pledger W and Dalton W. (2000). Oncogene, 19, 4319-4327.

Horita M, Andreu E, Benito A, Arbona C, Sanz C, Benet I, Prosper F and Fernandez-Luna J. (2000). J. Exp. Med., 191, $977-984$

Ibrado A, Huang Y, Fang G, Liu L and Bhalla K. (1996). Cancer Res., 56, 4743 - 4748.

Ilaria RL and Van Etten RA. (1996). J. Biol. Chem., 271, $31704-31710$.

Jain S, Susa M, Keeler M, Carlesso N, Druker B and Varticovski L. (1996). Blood, 88, 1542-1550.

Jiang K, Zhong B, Gilvary D, Corliss B, Hong-Geller E, Wei $\mathrm{S}$ and Djeu J. (2000). Nature Immunol., 1, 419.

Jonuleit $T$, Peschel $C$, Schwab $R$, van der Kuip $H$, Buchdunger E, Fischer T, Huber $\mathrm{C}$ and Aulitzky WE. (1998). Br. J. Haematol., 100, 295-303.

Kolibaba K, Bhat A, Heaney C, Oda T and Druker B. (1999). Leuk. Lymphoma, 33, 119-126.

Kraker A, Hartl B, Amar A, Barvian M, Showalter H and Moore C. (2000). Biochem. Pharmacol., 60, 885-898.

Landowski T, Shain K, Oshiro M, Buyuksal I, Painter J and Dalton W. (1999). Blood, 94, 265-274.

Lin T, Mahajan S and Frank D. (2000). Oncogene, 19, $2496-$ 2503.

Lionberger J, Wilson M and Smithgall T. (2000). J. Biol. Chem., 275, $18581-18585$.

Lord J, McIntosh B, Greenberg P and Nelson B. (2000). J. Immunol., 164, 2533-2541.

Lugo T, Pendergast A, Muller A and Witte O. (1990). Science, 247, 1079-1082.

Mes-Masson A, McLaughlin J, Daley G, Paskind $\mathrm{M}$ and Witte O. (1986). Proc. Natl. Acad. Sci. USA, 83, $9768-$ 9772.

Nagar B, Bornmann W, Pellicena P, Schindler T, Veach D, Miller T, Clarkson B and Kuriyan J. (2002). Cancer Res., 62, 4236-4243. 
Nelson KL, Rogers JA, Bowman TL, Jove R and Smithgall TE. (1998). J. Biol. Chem., 273, $7072-7077$.

Nieborowska-Skorska M, Wasik M, Slupianek A, Salomoni P, Kitamura T, Calabretta B and Skorski T. (1999). J. Exp. Med., 189, $1229-1242$.

Nimmanapalli R, O’Bryan E, Huang M, Bali P, Burnette PK, Loughran T, Tepperberg J, Jove R and Bhalla K. (2002). Cancer Res. in press.

Obaya A, Mateyak M and Sedivy J. (1999). Oncogene, 18, $2934-2941$.

Onishi M, Nosaka T, Misawa K, Mui A, Gorman D, McMahon M, Miyajima A and Kitamura T. (1998). Mol. Cell. Biol., 18, 3871-3879.

Pendergast A, Muller A, Havlik M, Maru Y and Witte O. (1991). Cell, 66, 161-171.

Porosnicu M, Nimmanapalli R, Nguyen D, Worthington E, Perkins C and Bhalla K. (2001). Leukemia, 15, 772-778.

Puil L, Liu J, Gish G, Mbamalu G, Bowtell D, Pelicci P, Arlinghaus R and Pawson T. (1994). EMBO J., 13, $764-$ 773.

Reynolds J, Yang T, Qian L, Jenkinson J, Zhou P, Eastman A and Craig R. (1994). Cancer Res., 54, 6348-6352.

Rhodes J, York R, Tara D, Tajinda K and Druker B. (2000). Exp. Hematol., 28, 305-310.

Roumiantsev S, de Aos I, Varticovski L, Ilaria R and Van Etten R. (2001). Blood, 97, 4-13.

Rowley J. (1973). Nature, 243, $290-293$.

Sawyers C, Callahan W and Witte O. (1992). Cell, 70, $901-$ 910.

Schwaller J, Parganas E, Wang D, Cain D, Aster JC, Williams IR, Lee CK, Gerther R, Kitamura T, Frantsve J, Anastasiadou E, Loh ML, Levy DE, Ihle JN and Gilliland DG. (2000). Mol. Cell, 6, 693-704.
Sexl V, Piekorz R, Moriggl R, Rohrer J, Brown M, Bunting K, Rothammer K, Roussel M and Ihle J. (2000). Blood, 96, $2277-2283$.

Sillaber C, Gesbert F, Frank D, Sattler M and Griffin J. (2000). Blood, 95, 2118-2125.

Sinibaldi D, Wharton W, Turkson J, Bowman T, Pledger W and Jove R. (2000). Oncogene, 19, 5419-5427.

Smithgall TE, Briggs SD, Schreiner S, Lerner EC, Cheng H and Wilson MB. (2000). Oncogene, 19, 2612-2618.

Socolovsky M, Fallon A, Wang S, Brugnara C and Lodish H. (1999). Cell, 98, $181-191$.

Song J and Grandis J. (2000). Oncogene, 19, 2489-2495.

Sonoyama J, Matsumura I, Ezoe S, Satoh Y, Zhang X, Kataoka Y, Takai E, Mizuki M, Machii T, Wakao H and Kanakura Y. (2002). J. Biol. Chem., 277, 8076-8082.

Thiesing J, Ohno-Jone SS, Kolibaba K and Druker B. (2000). Blood, 96, 3195-3199.

Turkson J, Bowman T, Garcia R, Caldenhoven E, De Groot R and Jove R. (1998). Mol. Cell. Biol., 18, 2545-2552.

Wei S, Gilvary D, Corliss B, Sebti S, Sun J, Straus D, Leibson P, Trapani J, Hamilton A, Weber M and Djeu J. (2000). J. Immunol., 165, 3811.

Wisniewski D, Lambek C, Liu C, Strife A, Veach D, Nagar B, Young M, Schindler T, Bornmann W, Bertino J, Kuriyan J and Clarkson B. (2002). Cancer Res., 62, $4244-4255$.

Yu C, Meyer D, Campbell G, Larner A, Carter-Su C, Schwartz J and Jove R. (1995). Science, 269, $81-83$.

Zhou P, Qian L, Kozopas K and Craig R. (1997). Blood, 89, $630-643$.

Zong CS, Zeng L, Jiang Y, Sadowski HB and Wang LH. (1998). J. Biol. Chem., 273, $28065-28072$. 